\title{
PRIMARY CELL CULTURE OF AEDES ALBOPICTUS MIDGUT CELLS: A PROSPECTIVE MODEL FOR IN VITRO STUDY OF ARBOVIRUSES
}

\author{
ENAKSHI ROY ${ }^{1}$, MOONMOON SINHA ${ }^{1}$, SHAILJA KATOCH ${ }^{1}$, URMITA CHAKRABORTY ${ }^{1}$, SATADAL DAS ${ }^{1 *}$, \\ DEBABRATA SARKAR ${ }^{1}$, DEBADATTA NAYAK ${ }^{2}$, ANIL KHURANA ${ }^{2}$, RAJ KUMAR MANCHANDA ${ }^{2}$
}

\begin{abstract}
${ }^{1}$ Department of Virology, Dr. Anjali Chatterjee Regional Research Institute for Homoeopathy, Kolkata, West Bengal, India. ${ }^{2}$ Central Council for Research in Homoeopathy, Ministry of AYUSH, Government of India, New Delhi, India. Email: drsatdas@hotmail.com
\end{abstract}

Received: 13 April 2017, Revised and Accepted: 28 June 2017

ABSTRACT

Objective: Midgut cells play a key role in the propagation of mosquito borne Arboviruses. The existing mosquito cell lines for studying viral pathogenesis are derived either from larvae or from eggs since there is no cell line available from the mosquito midgut. Therefore, to delineate the in situ viral interaction which naturally occurs within the mosquito midgut and represent cellular pathogenesis in human beings, the present work was aimed to develop a primary cell line from the midgut cells of Aedes albopictus.

Methods: The midgut cells of A. albopictus were collected, cultured and incubated at $28^{\circ} \mathrm{C}$ to study the growth after every 24 hrs for 7 days.

Result: The primary cell culture showed an increasing growth pattern of columnar cells up to $48 \mathrm{hrs}$ followed by decrease in cell population afterward. However, the number of stem cells increased significantly throughout the study period, and their population outnumbered the columnar cells after $72 \mathrm{hrs}$. There was no significant change of goblet cells and regenerating cells which were scanty in number throughout the experiment.

Conclusion: The present method will help to develop the individual cell lines from mosquito midgut and study the host pathogen interaction in arboviral diseases in future.

Keywords: Aedes albopictus, Midgut, Stem cells, Columnar cells.

(C) 2017 The Authors. Published by Innovare Academic Sciences Pvt Ltd. This is an open access article under the CC BY license (http://creativecommons. org/licenses/by/4. 0/) DOI: http://dx.doi.org/10.22159/ajpcr.2017.v10i10.19136

\section{INTRODUCTION}

Arboviral diseases have emerged as a major human health concern and have now become one of the most important causes of mortality and morbidity, especially in the tropical countries. Among the different arboviral diseases, mosquito borne diseases are the most predominating, and their worldwide upsurge can be directly attributed to the proliferation and adaptation of these vectors to the favorable climatic conditions in the tropical and subtropical countries due to global warming [1]. It has been estimated that over half of the global population is at risk of infection with one of four dengue virus serotypes (DENV-1, -2, -3, and -4) [2]. Petersen and Marfin reported that yellow fever, dengue fever, Japanese encephalitis, and West Nile fever viruses collectively cause millions of infections and tens of thousands of deaths each year [3]. Due to unavailability of proper representation system which may imitate the host pathogen interactions, universally accepted vaccine and drug regimens are still unavailable to combat these lifethreatening diseases. In arboviral diseases such as dengue, Zika, West Nile, and yellow fever virus, the virus conduction from infected humans to mosquitoes occurs through an infectious blood meal and the midgut cell membrane is the portal of entry as well as the first cellular barrier where the virus interacts to establish infection [4]. The virus penetrates into the midgut epithelium, replicate, crosses the escape barrier, and disseminates into the salivary gland of the infected mosquitoes, from where the virus is transmitted to a new vertebrate host [4]. Therefore, it is important to have a clear understanding of the vector-virus interactions, which may enable predictions of how these viruses can establish infections, disseminate from one organ to another and ultimately be applied to the development of more efficient disease control strategies. At present, the mosquito cell lines available so far for studying virus cellular pathogenesis are derived either from larvae or from eggs [5], and no cell line derived from the midgut cells of adult mosquitoes are currently available. Hence, in this study, a novel approach has been made to develop a primary cell culture from midgut of Aedes albopictus to serve as a model for learning pathogenesis of various mosquito borne viral diseases.

\section{METHODS}

Collection and identification of $\boldsymbol{A}$. albopictus mosquitoes A. albopictus mosquitoes were collected from Dakshineswar, Kolkata. The mosquitoes were initially identified by morphological examination [6]. Further authentication of the mosquitoes was done by ITS1 polymerase chain reaction (PCR) using the primers described elsewhere [7] with minor modifications in the PCR conditions, i.e., $95^{\circ} \mathrm{C}$ for 5 minutes; 35 cycles of $95^{\circ} \mathrm{C}$ for 30 seconds; $47^{\circ} \mathrm{C}$ for 30 seconds; $72^{\circ} \mathrm{C}$ for 2 minutes; $72^{\circ} \mathrm{C}$ for 4 minutes (Fig. 1)

\section{Isolation of midgut cells and culture}

The isolation and culture of midgut cells were done according to our previously published study [8] with some modifications. Briefly, the mosquitoes were kept at low temperature $\left(\sim 4^{\circ} \mathrm{C}\right)$ and then washed with distilled water, $70 \%$ alcohol and phosphate buffered saline (PBS) $[9,10]$. The mosquitoes were then dissected by placing on a drop of PBS on a glass slide, followed by separation of the midgut. The midguts were gently macerated to prepare a homogeneous cell suspension in Dulbecco's modified Eagle's medium (DMEM) [11]. After counting the cells by hemocytometer, $1.2 \times 10^{6}$ cells were seeded per well containing complete DMEM (Gibco, USA) and incubated at $28^{\circ} \mathrm{C}$. The cell population was observed and identified microscopically every 24 hrs till 144 hrs [12] to study the growth pattern of different midgut cells. The culture medium was changed after every $48 \mathrm{hrs}$.

The number of columnar and stem cells were counted per square centimeters selected randomly in different areas followed by statistical analysis of the data. The experiment was repeated thrice, and the data 
are presented as a mean \pm standard deviation. G-test was performed to find the association of changes in the number of columnar and stem cells with time using "DescTools" in R software (version 3.2.1).

Scanning electron microscopic (SEM) study

The cultured cells were fixed [13], sputter-coated in Quorum (SC7620 sputter coater) and then subjected to SEM to visualize the cells and

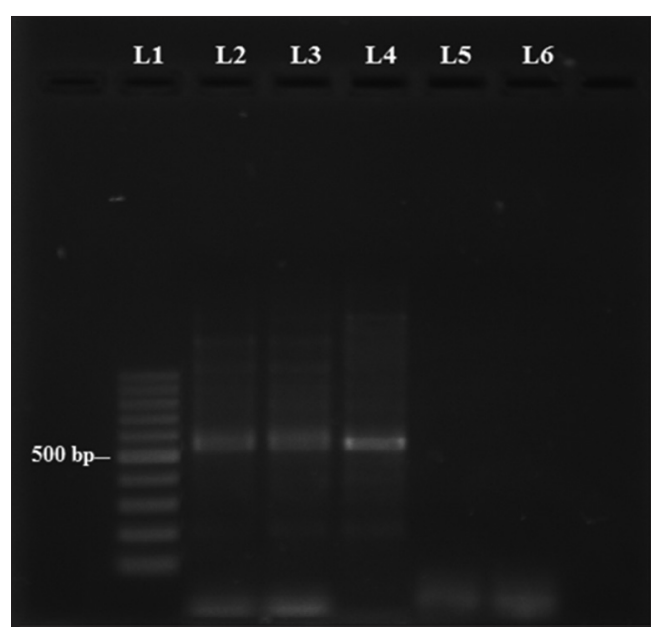

Fig. 1: Authentication of Aedes albopictus cells by ITS1 gene amplification using AUF and AUR primers. Lane L1: 100 bp ladder; Lane L2-3: ITS1 gene amplicon (577 bp) from A. albopictus midgut primary cell culture; Lane L4: ITS1 gene amplicon (577 bp) from A. albopictus midgut cells; Lane L5: Negative control (Armigeres subalbatus); Lane L6: Negative control (Culex quinquefasciatus) microvilli on the surface of columnar cells using EV018 Research Carl Zeiss, (Germany) scanning electron microscope at 0-20 kV accelerating voltage.

\section{RESULT}

Identification of $A$. albopictus

Primary identification of $A$. albopictus mosquito was done on the basis of morphological characteristics followed by molecular confirmation. The result showed 577 bp partial coding fragment of ITS1 gene (Fig. 1) which authenticated the source of cells to be from A. albopictus.

\section{In vitro growth pattern of midgut cell population}

Three different types of cell population were observed in the midgut cell culture constituting with majority of columnar and stem cells followed by very few number of goblet cells. The study of the growth pattern of columnar and stem cells showed that overall the number of columnar cells were higher than the stem cells at the early phase of the primary cell culture. The number of columnar cells (Fig. 2) gradually increased up to $48 \mathrm{hrs}$, and then the rate of proliferation remained the same till 96 hrs after which the rate decreased (Fig. 3a). However, their population was significantly outnumbered by stem cells (Fig. 2) after 72 hrs which was initially trivial compared to columnar cells but increased significantly from $0 \mathrm{hr}$ till the final observation at $144 \mathrm{hrs}$ (Fig. 3b). The day wise changes in population of columnar and stem cells in the cell culture are depicted in Figs. 2 and 4.

The G-test analysis of the data revealed significant association of the growth pattern of different cell populations with time. For columnar cells, $\mathrm{G}=35.2854$, $\mathrm{p}<0.0001$ and for stem cells, $\mathrm{G}=550.0616, \mathrm{p}<0.0001$.

\section{SEM study of the cells}

The SEM images showed the morphology of the columnar cells and stem cells at $\mathrm{k} \times 1.16$ magnification (Fig. 5a). At higher magnification
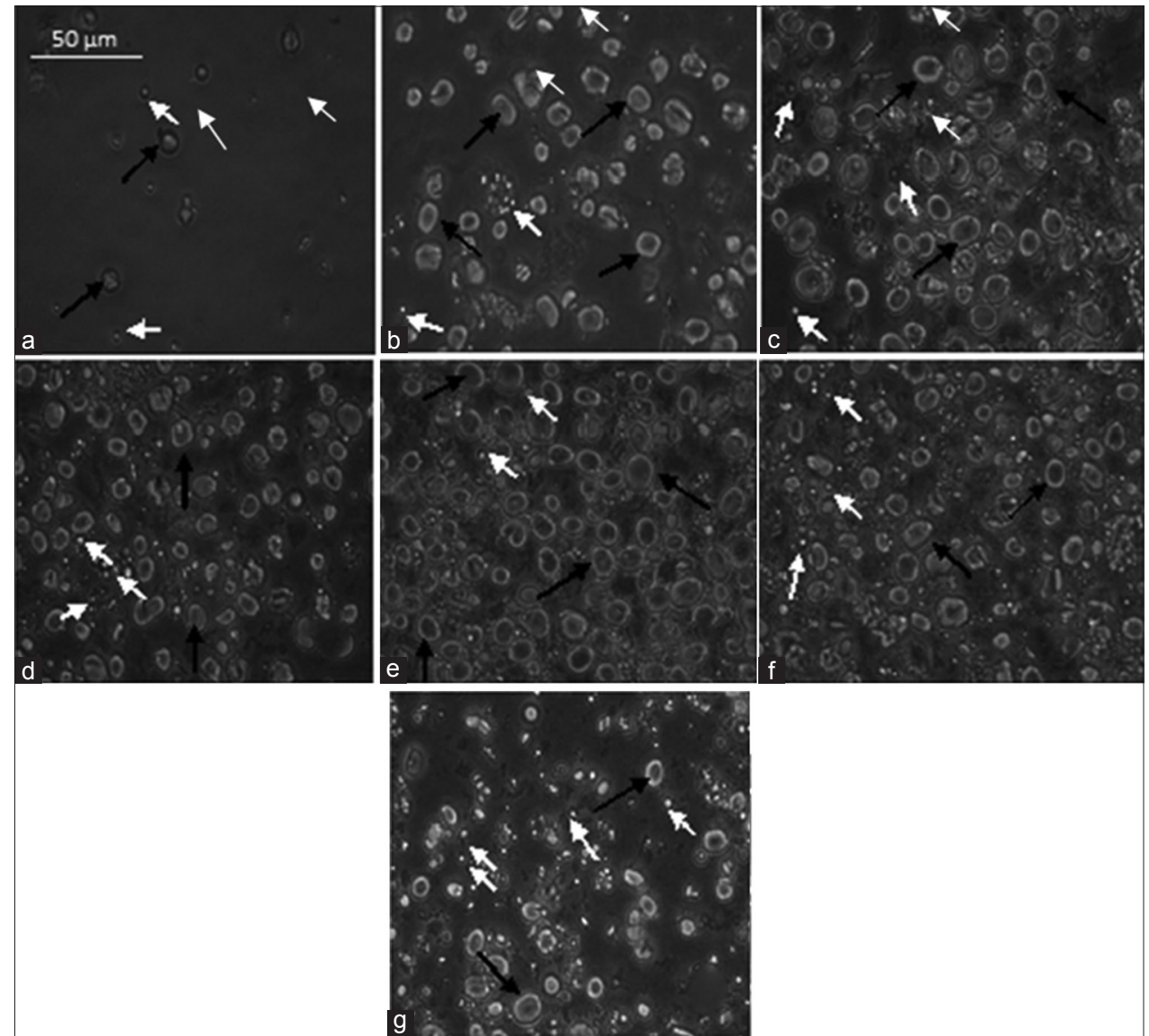

Fig. 2: Representative photographs are showing the pattern of changes of columnar (black arrows) and stem cells (white arrows) at different time intervals. (a) 0 hr, (b) 24 hrs, (c) 48 hrs, (d) 72 hrs, (e) 96 hrs, (f) 120 hrs, and (g) 144 hrs 


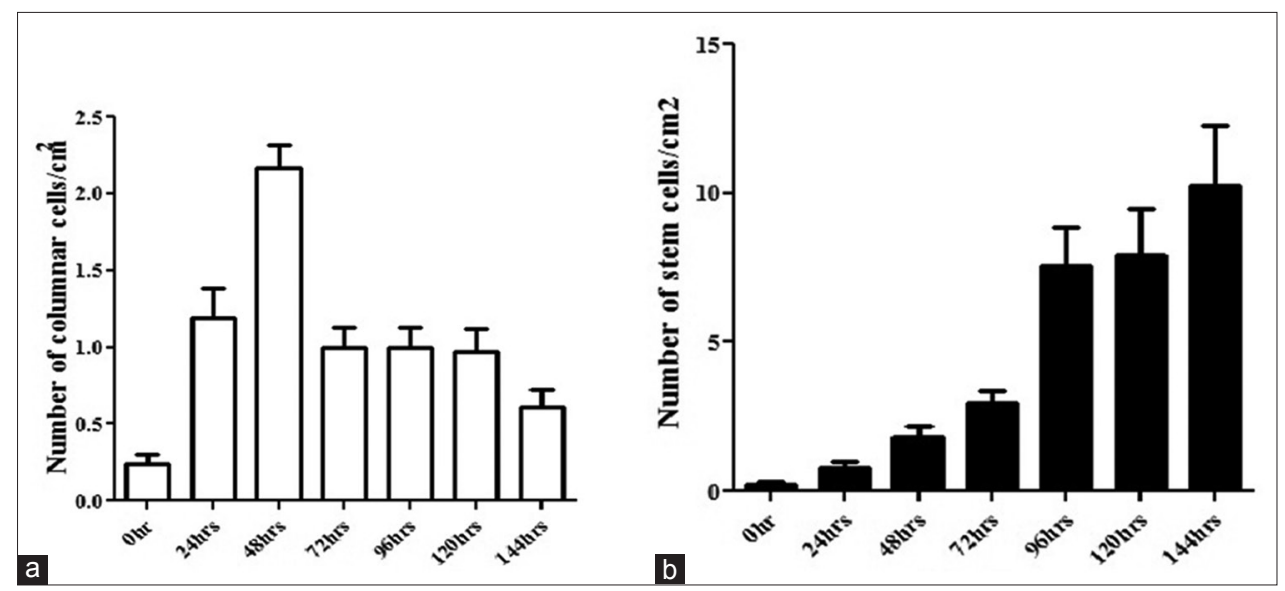

Fig. 3: Bar diagram representing the growth of columnar and stem cells at different time intervals. (a) Increasing growth pattern of columnar cells till 48 hrs after which they attained a stationary phase until 96 hrs, and after that, the growth rate decreased. (b) The growth rate of stem cells increased almost exponentially, although the growth rate at 96 and $120 \mathrm{hrs}$ was almost same

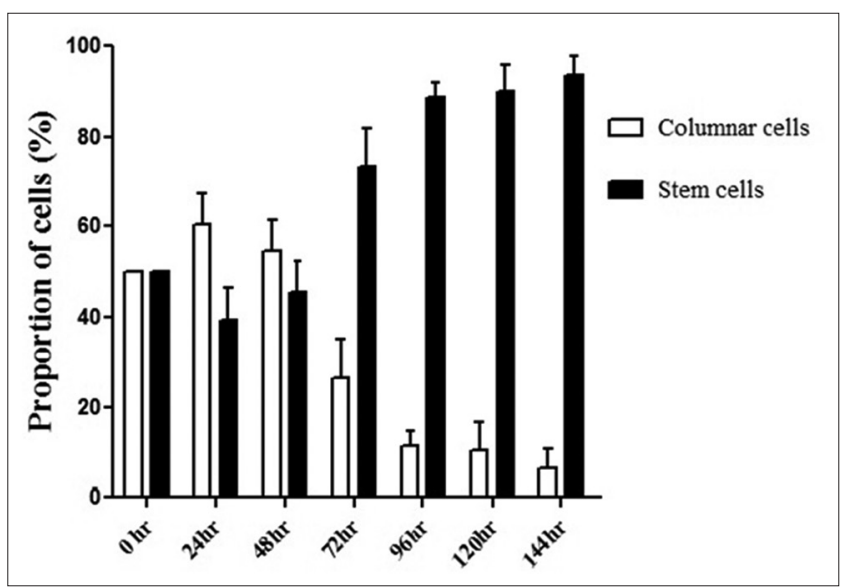

Fig. 4: The relative changes of cell populations. The figure shows the average proportion of columnar and stem cells obtained after 5 repeated experiments and observed after $24 \mathrm{hrs}$ up to $144 \mathrm{hrs}$

$(\mathrm{k} \times 20)$, the microvilli on the surface of the columnar cells were also visualized (Fig. 5b).

\section{DISCUSSION}

The global burden of mosquito borne arboviral and parasitic diseases is increasing worldwide as a result of global warming, which attributes to favorable climatic conditions for mosquitoes to breed and proliferate. The mosquito midgut plays an important role in pathogen entry and multiplication. This suggests the requirement of more studies focusing on the midgut, its physiology and the way it interacts with parasites and viruses $[14,15]$. Few reports are available on the in vitro primary culture of stem cells derived from the midgut of various insects [16]. Further studies for identification of the factors influencing the stem cell proliferation, differentiation and to develop an ideal model to study host pathogen interactions are required. However, no such attempt has been made for establishment of primary cell cultures from the adult mosquito midgut cells so far. The present study reports a novel attempt to develop an in vitro primary culture of mosquito midgut cells. The midgut cells of A. albopictus were isolated, and the cell source was authenticated by PCR after development of primary cell culture. During the study period, the in vitro growth pattern of two major midgut cell types was observed simultaneously in a primary cell culture which may mimic the in vivo microenvironment of the mosquito midgut. However, to study the host virus interaction, it is important to isolate the
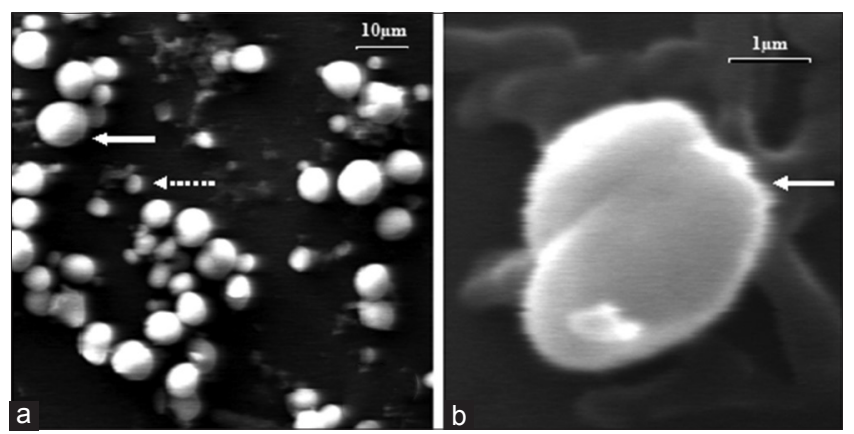

Fig. 5: (a) A sheet of columnar cell (continuous arrow) and stem cells (dotted arrow) under scanning electron microscopy at k×1.16 magnification (b) columnar cells with prominent microvilli (arrow) at $\mathrm{k} \times 20$ magnification

columnar cells from primary cell culture as they are the major target for virus infection in mosquitoes [12]. As from the present study, it was observed that the growth of columnar cells was increasing till $72 \mathrm{hrs}$ after which it decreased, therefore, it is important to establish an immortal cell line from midgut columnar cells of adult mosquitoes to assist in further studies.

Flavivirus infection in the mosquito occurs through columnar cells present in the posterior part of midgut which contain a lower number of microvilli [12]. Hence, in this study, an attempt was made to visualize the microvilli on the surface of the columnar cells of A. albopictus midgut at higher magnification by SEM. Although microvilli were present on the cell surface of the columnar cells, the photographs did not differentiate less or more number of microvilli on different columnar cells. In the midgut, the columnar cells are produced from stem cells. Stem cells develop to regenerative cells, and these cells further differentiate to columnar and goblet cells [17]. The differentiation of stem cells to columnar cells with plenty of microvilli or with sparse number of microvilli is not properly explained so far. Therefore, it is not known if columnar cells with lower numbers of microvilli are from early or late stages of differentiation. In our previous experience, we observed that the DENV could propagate easily in stem cells. It is reported that midgut cells retain some proliferative potential since damaged midgut is rapidly repaired by cell proliferation [12]. Recently, a significant number of studies on cell lines are going on mostly on anticancer studies of different herbal medicines [18,19], however, studies on mosquito cell line are only a few. Thus, this study will enlighten this relatively dark area of cell biology. 


\section{CONCLUSION}

The primary mosquito midgut cell culture that we developed may help other researchers further standardize this procedure. The columnar cell in the primary culture, as well as the successive generation of stem cells, may help in studying the host pathogen interaction in in vitro model.

\section{ACKNOWLEDGMENTS}

We acknowledge Central Council for Research in Homoeopathy, Under Ministry of AYUSH, New Delhi, India, for the financial support. We also thank Professor A.K. Hati, Ex-Director and Head, Department of Entomology, School of Tropical Medicine, Kolkata, India, for the morphological identification of $A$. albopictus mosquitoes.

\section{REFERENCES}

1. Dash AP, Bhatia R, Sunyoto T, Mourya DT. Emerging and reemerging arboviral diseases in Southeast Asia. J Vector Borne Dis 2013;50(2):77-84.

2. Durbin AP, Mayer SV, Rossi SL, Amaya LI, Ramos CJ, Eong OE, et al. Emergence potential of sylvatic dengue virus Type 4 in the urban transmission cycle is restrained by vaccination and homotypic immunity. J Virol 2013;439(1):34-41

3. Petersen LR, Marfin AA. Shifting epidemiology of Flaviviridae. J Travel Med 2005;12 Suppl 1:S3-11.

4. Franz AW, Kantor AM, Passarelli AL, Clem RJ. Tissue barriers to arbovirus infection in mosquitoes. Viruses 2015;7(7):3741-67.

5. Walker T, Jeffries CL, Mansfield KL, Johnson N. Mosquito cell lines: History, isolation, availability and application to assess the threat of arboviral transmission in the United Kingdom. Parasit Vectors 2014;7:382.

6. Service M. Medical Entomology for Students. $4^{\text {th }}$ ed. New York: Cambridge University Press; 2008. p. 53-80.

7. Das M, Das MK, Dutta P. Genetic characterization and molecular phylogeny of Aedes albopictus (Skuse) species from Sonitpur district of Assam, India based on COI and ITS1 genes. J Vector Borne Dis
2016;53(3):240-7.

8. Sinha M, Roy E, Das S, Sarkar DB, Nayak D, Khurana A, et al. An observation on direct changes in Aedes albopictus midgut cells by Rhus tox $6 \mathrm{C}$ in relation to dengue virus infection. Indian J Res Homoeopath 2016;10:258-65.

9. Hamer GL, Anderson TK, Berry GE, Makohon-Moore AP, Crafton JC, Brawn JD, et al. Prevalence of filarioid nematodes and trypanosomes in American robins and house sparrows, Chicago USA. Int J Parasitol Parasites Wildl 2012;2:42-9.

10. Sadrud-Din S, Loeb M, Hakim R. In vitro differentiation of isolated stem cells from the midgut of Manduca sexta larvae. J Exp Biol 1996;199:319-25.

11. Brackney DE, Scott JC, Sagawa F, Woodward JE, Miller NA, Schilkey FD, et al. C6/36 Aedes albopictus cells have a dysfunctional antiviral RNA interference response. PLoS Negl Trop Dis 2010;4(10):e856

12. Zieler H, Garon CF, Fischer ER, Shahabuddin M. A tubular network associated with the brush-border surface of the Aedes aegypti midgut: Implications for pathogen transmission by mosquitoes. J Exp Biol 2000;203:1599-611.

13. Fischer ER, Hansen BT, Nair V, Hoyt FH, Dorward DW. Scanning electron microscopy. Curr Protoc Microbiol 2012; Chapter 2:Unit 2B.2.

14. Billingsley PF. Vector-parasite interactions for vaccine development. Int J Parasitol 1994;24:53-8.

15. Shahabuddin M, Cociancich S, Zieler H. The search for novel malaria transmission-blocking targets in the mosquito midgut. Parasitol Today 1998;14(12):493-7.

16. Hakim RS, Caccia S, Loeb M, Smagghe G. Primary culture of insect midgut cells. In Vitro Cell Dev Biol Anim 2009;45(3-4):106-10.

17. Hakim RS, Baldwin KM, Loeb M. The role of stem cells in midgut growth and regeneration. In Vitro Cell Dev Biol Anim 2001;37(6):338-42.

18. Sushama MA, Kumaresan R. Study on in vitro cytotoxicity of papain against liver cancer cell line Hep G2. Int J Pharm Pharm Sci 2014;6(9):160-1.

19. Aishwarya V, Abdulla SS, Dheeba B, Renuka R. In vitro antioxidant and anticancer activity of Cardiospermum halicabum L against EAC cell line. Int J Pharm Pharm Sci 2014;6(8):263-8. 